\title{
Challenges of Biopiracy: Implementing Community Based Eco- tourism (CBET) in the Sri Lankan context
}

\author{
H.I.G.C. Kumara \\ Deaprtment of Geography, University of Ruhuna, Sri Lanka
}

Date Received: 16-09-2016

Date Accepted: 24-12-2016

\begin{abstract}
Protecting the right of the local community/country to use their own genetic resources available in a particular area is an important element of environmental and biodiversity conservation. However, one of the biggest biodiversity conservation challenges faced by southern peripheral countries is biopiracy and related issues. Community based ecotourism (CBET) is a well-established concept and its implementation is an important component in many regional development strategies. This research argues that though CBET which originated as a western concept has been successfully applied in number of projects, it generates biopiracy challenges in its implementation when CBET operates within different geo-political, economic and cultural contexts. This research examines such challenges to CBET initiatives in the Sinharaja world heritage site, Sri Lanka. A qualitative-inductive research methodology has principally guided this research to examine the socio-cultural and socio-economic context of biopiracy issues. A total of 293 participants have informed this research including 193 interviews. A critical discourse analysis (CDA) method is used to examine both primary qualitative data collected through participant and direct observation, interviews and secondary data. One of the main findings is that despite plans being developed at a community level, in wider context, challenges of biopiracy related to superimposed capitalism contest CBET ideologies. Superimposed capitalism results in individualistic and competitive behaviours that undermine collaborative and responsible community approach. Presently, smuggling out of Wallapatta plant (Gyrinops walla) and gathering of Spotted bowfinger gecko (Cyrtodactylus triedra) which is an endemic nocturnal reptile species have become profitable in KudawaSinharaja site and a growing number of biopirates venture into here. Local community of this site takes risks in forest genetic resources smuggling because it provides them with the means of earning much money within a short period. Regardless of all prevalent laws and regulations against bioprospecting, biopiracy, biological resource and wildlife smuggling, authorities have still failed to control these activities in this site because of the support given to bio-pirates by the local community. The research concludes that CBET is an appropriate pathway for tourism development in Sri Lanka but recognition of biopiracy issues associated with superimposed capitalism is required and needed to be addressed. A well-defined monitoring system and an effective legal framework to control adverse effects are important for achieving CBET goals while confronting biopiracy.
\end{abstract}

Keywords: Biopiracy, Community Based Eco-tourism, Superimposed capitalism.

*Correspondence: chamindakumara03@yahoo.com

Tel: +94714469539

ISSN 2235-9370 Print/ISSN 2235-9362 Online (C) University of Sri Jayewardenepura 


\section{Introduction}

Most poor and developing countries of the world want to develop their economies as greater wealth, on the global stage, provides greater power. Economic development, though, was long jeopardized by colonial relations which seem difficult to overcome, even today. Different means of boosting economic growth have been tried, following different political outlooks. Western development theories and discourses have heavily influenced the development process of southern peripheral countries based on two main reasons. First, the process of globalization has shrunk time and space barriers and western knowledge easily flows into developing world. Second, geo-politically as well as economically southern peripheral countries depend heavily on the western world and it leads to core-peripheral dependency on western knowledge (Clark, 2008).

More recently, some countries have turned to tourism, which has become a global practice, as a possible boost to their foreign exchange income and to reduce poverty. Domestic flows of tourists have also been encouraged to redistribute wealth within individual countries. However, here too, many southern peripheral countries have used western theories as the baseline in their tourism and ecotourism policies (Chaperon \& Bramwell, 2013). For instance, Sri Lanka changed its top to bottom forest management approach and created a new Forestry Sector Master Plan in 1995, following the bottom up development and sustainable development ideologies to achieve forest management, to empower marginalized local communities and to seek theoretical and practical answers for contemporary forestry sector issues (Vitarana \& Rakaganno, 1997). Under this master plan, eco-tourism and CBET approaches were at the centre of attention of environmental policy makers and researchers of the country (Dangal \& De Silva, 2010; Kahveci, Ok, \& Yýlmaz, 2011; Ngece, 2011). Ecotourism, in this article is defined as 'environmental friendly responsible travel' links to sustainable development. As well, CBET emphasizes 'the roots or underling principles derived from concepts of community developmenta small scale locally oriented and holistic approach to economic growth and social change' linked to the idea of spreading benefits to the whole community, or at least to the largest number as possible to help improve its economic outlook. Critics, using post colonialism and sustainable development ideas have helped to build up the rationality of this approach (Brydon, 2004; Ziai, 2011).

Moreover, Sri Lanka is a developing island country in South Asia, rich in extensive biodiversity owing to its geo-physical positioning in a tropical climate zone (Lynam, Jong, Sheil, Kusumanto, \& Evans, 2007). Among the different types of eco-systems, tropical rain forests of Sri Lanka have become most attractive and biologically precious for their recorded high biodiversity and endemic species rates (Brand, 2012). Among all the rain forests of Sri Lanka, Sinharaja is the biggest, consisting of 11,187 hectares spread over an elevation range of 150$1150 \mathrm{~m}$ above sea level and first declared world natural heritage biological unit of Sri Lanka by UNESCO in 1988 (Forest Department, 2014).

Even if tea planting has become popular in these areas as a better income source, finding land for cultivation has become a major problem for the new generation. Before the 1990s, farmers illegally cleared forestland for their cultivation needs, yet now the rules and regulation against forest clearance have been tightened. Therefore, it has become very difficult for young people to clear forest areas for farming and they always clash with forest officers in their struggle 
to find new land for cultivation needs (Kumara, 2010). On the other hand, increasing human population and youth unemployment have become common in this area, the poverty rate has increased, so that the local community is economically marginal (Forest Department, 2013a). To meet these challenges, the government and the Forest Department together proposed implementing of CBET in this site.

Implementing CBET in the Kudawa-Sinharaja context seems ideologically rational, however, owing to many contextual challenges, project planners have failed to achieve its sustainability goals which are based on western ideological dimensions (Forest Department, 2013a). Since biopiracy is one of the prominent issues among all these challenges, it is focused in this article. Protecting the right of the local community/country to use their own genetic resources available in a particular area is an important element of environmental and biodiversity conservation (Kamau, 2009; Sampath, 2005). However, one of the main challenges of biodiversity conservation in the Southern Peripheral countries is biopiracy which simply can be defined as the 'commercial use of genetic resources or indigenous knowledge without obtaining permission or properly paying the relevant community or country' (Mgbeoji, 2005; Sharma, 2012).

These issues are common in bottom up development and sustainable development projects implemented in many other Southern Peripheral countries (Jalani, 2012; Reimer \& Walter, 2013; Thompson, 2008; Waylen, Gowan, \& Milner-Gulland, 2009) and a large gap between practical achievements and expected goals of these projects can still be seen. Taking this situation into consideration, this research focuses on carrying out a comparative analysis of challenges of biopiracy in the Kudawa-Sinharaja CBET site.

\section{Research methodology}

\subsection{Research site}

The research field, the Kudawa GND which is an isolated area among all the administration units of Sri Lanka is located close to Sinharaja. One of the route accesses to Sinharaja is through Kudawa GND, namely, the Kudawa-Sinharaja entrance (see Figure 1).

\section{2 'Qualitative Research Methodology' and 'Inductive research approach'}

The challenges of biopiracy in CBET in this site are based on deep-rooted socio-cultural, and socio-economic factors, which operate hidden in the society, besides, respondents were not necessarily ready to discuss them openly. Therefore, in this research primary concern was to deal with 'rich and deep' primary data rather than 'numeric' data and much attention been paid to qualitative research methodology.

This study targeted to collect philosophies on how 'rich' and 'deep' are intangible factors associated with biopiracy issues, such as cultural changes, local knowledge, geopolitics and local economic wealth. Consequently, a 'qualitative inductive research approach' was selected as the dominant methodological approach of this research. There is a profound correlation between qualitative methodology and inductive research. In inductive research, first, data is collected using relevant qualitative data collecting methods and then findings are linked with relevant theories, discourses, and concepts. 
This is the opposite way to conducting a 'quantitative-deductive research', so it is called a 'bottom up' research approach (Bryman, 2012; Thomas, 2012). Suitability of qualitative inductive research approach to this research is its ability to provide complex textual descriptions of how people experience a given research issue. It provides information about the 'human' side of an issue - that is, the often-contradictory behaviours, beliefs, opinions, and relationships of individuals.

\subsection{Data collecting methods:}

Secondary data in the research is extracted from the following sources. A number of publications by local and international writers, especially those that include information about development discourses, alternative development, eco development, ecotourism, community forest management, joint forest management, tropical forest management etc. are used in the study.

Participant and direct observation, semi-structured interviews and focus group interviews were conducted as qualitative data collection methods for this research. Altogether, 115 semi structured interviews were conducted in this research and each interviewee was provided with a consent form too. Semi-structured interviews are presented by their categorical code. For instance, in 'SSI10 Site guides of Sinharaja', 'SSI10' stands for 'semi structured interviewing number 10. Ten focused group interviews also have been conducted to the primary data collection process of this research and it is also presented by categorical code as 'FGI4 Visitors (local)': 'FGI4' indicates 'focused group interviewing number 04'. A total of 293 participants have informed this research including 193 interviews.

\subsection{Sampling method}

Semi-structured interviews use the 'snow-balling' sampling method. Snow-balling is based on the metaphor that when a real snow ball is rolling down the hill, its size gradually increases until it approaches saturation (Baker, 2012; Cohen \& Arieli, 2011; Dodds, 2014). Thus, the researcher must gather enough data using a chain referral process until it approaches saturation (Baltar \& Brunet, 2012). This method was useful in this research, since it helped to gather information from diverse respondents. As well, it helped to examine sensitive and confidential personal information important for the research objective (Longhurst, 2009).

\subsection{Analysis}

A critical discourse analysis (CDA) method was used to examine both primary qualitative data, which were collected through participant and direct observation, interviews as well as secondary data. The data was analysed using steps such as data understanding, categorizing, coding under themes, connecting with theories and discourses and described narratively (Description/Interpretation/Explanation) (Becker, 1958; Dewalt, 2011; Dey, 2003; May, 1997). Classification of themes from the collected raw data can be recognized as a process (Bryman, 2012). Intensive reading, careful reading and re-reading were conducted as a procedure to identify patterns in the data to recognize separate themes (Boyatzis, 1998; Fereday \& Cochrane, 2008). 


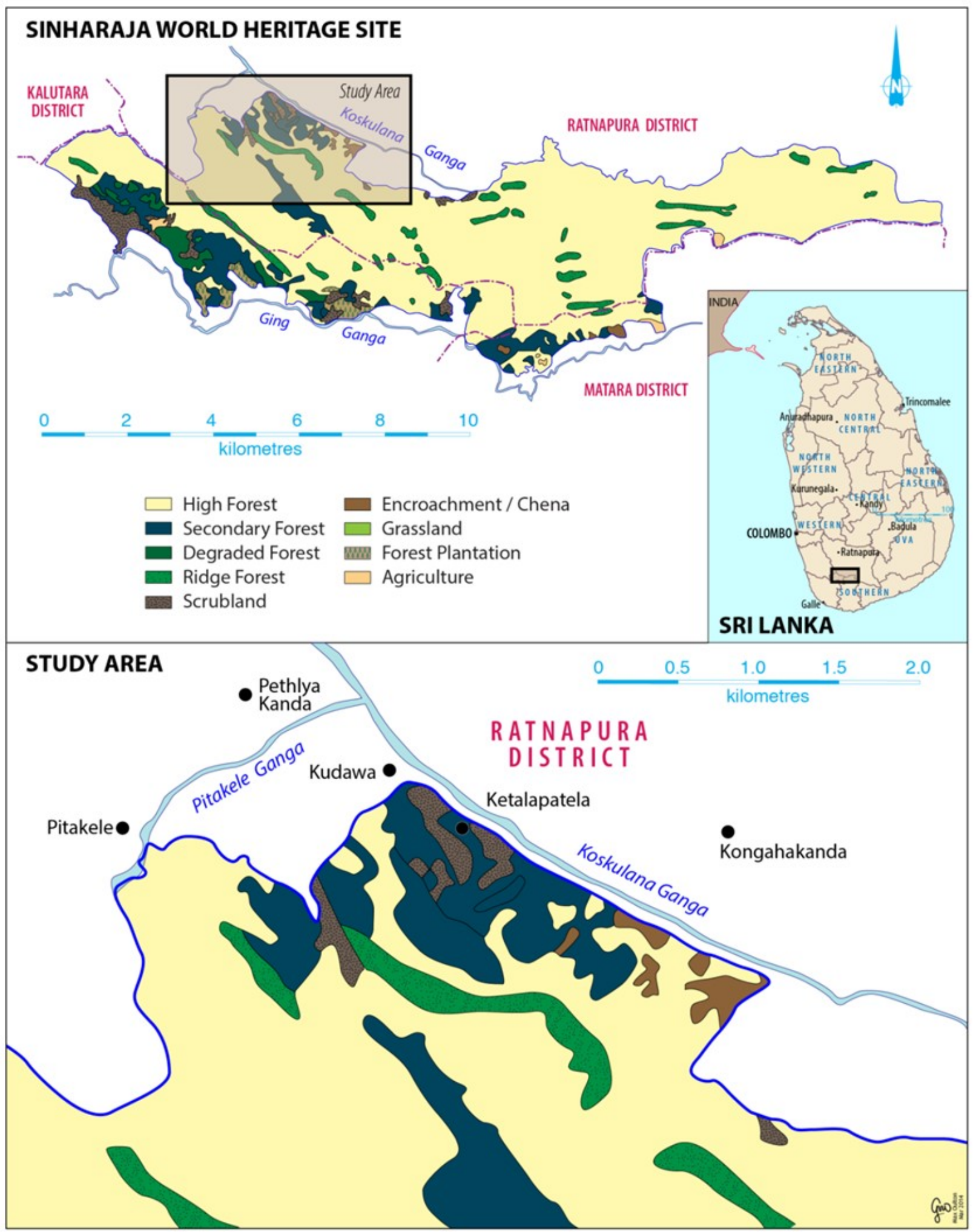

Figure 1: Location of the study area (drawn by Max Oulton) 


\subsection{Positionality and Reflexivity}

The notion of 'positionality and reflexivity' is normally connected with qualitative research methodology (Guillemin \& Gillam, 2004; Walker et al., 2013). Every human being lives in a highly connected socio-cultural and political network. The nature of that network is different from place to place, culture to culture and time to time. That means every human being enjoys a special socio-cultural, economic and political 'position'. Whatever they do, talk, write, create etc., that 'position' is naturally displayed in their work. The social researcher is also a human being who has a separate 'position' that depends on his/her own socio-cultural values, beliefs, feelings and thoughts (Robert Wood Jonson Foundation, 2012). Many scholars have then argued that 'position' is exposed in many parts of a social research process (Walker et al., 2013). Since this research uses qualitative methodology, I (researcher) was concerned about my (researcher's) 'positionality' through reflexivity.

\section{Results}

\subsection{Capitalism, superimposed capitalism and individualism}

Most of the Kudawa villagers traditionally belong to the Kitul tapping caste which is considered a low caste according to the traditional Sri Lankan caste hierarchy (Silva, Sivaparagasam, et al., 2009) and the villagers marry within the village and caste and this was easy as within Sinhalese traditional feudal society 'cross-cousin marriages' are allowed (De Munck, 1998; McGilvray, 1982). This biological relationship helps to create 'collectivism' in the community and a 'collectivist economy'.

Our village was an isolated community until 1980 and most of the villagers depended on Kitul tapping and shifting cultivation for living and whole village acted as one unit [SSI42 Senior Kudawa villager (Male -78 years old), 2012.11 .01 (This statement was crosschecked and was proved by SSI22, 27, 31, 43, 26, 29, 13, 34,57, 41, 97, 94, 96)].

Until the 1980s Kudawa was an isolated society. When the 'tea economy' was introduced to Kudawa after the 1980s, the villagers started growing tea on their private lands. Later, CBET became popular in Kudawa. In practice, implementation of CBET is challenged by 'individualism' in southern peripheral countries as a result of the influence of superimposed capitalism. This situation is common to the Kudawa-Sinharaja site.

Economically our village was rapidly developing after the 1980s, because of ecotourism and tea planting. Currently, we have modern houses with facilities, and other infrastructure facilities such as roads, a medical centre, electricity etc. Our village is open to the world and we freely interact with other outside communities. However, villagers become more and more isolated souls and our social relations are very poor now. Everyone here is busy earning money [SSI44- 72 years old female Kudawa resident, 2014.11._(This statement was cross-checked and was proved by SSI22, 27, 31, 43, 26, 29, $13,34,41,97,102,101 \&$ FGI 03, 02)].

The change occurred in the village economy, and lifestyles of villagers due to ecotourism and it brought changes in peoples' perspectives as well. At present, the villagers not only are in a rat race to earn money but also compete with each other to gain better social status. 


\subsection{Biopiracy Challenges and CBET}

Genetic forest resource loss caused by wildlife trafficking and biological or genetic resource smuggling is one of the major environmental challenges faced by Sri Lanka and many other developing countries. Most of the indigenous people in these countries, as underlined by the environmentalist interviewed above, are unaware of the biological value of the most of genetic resources available in their natural environments and the importance of protecting them for their own future. They see only the immediate economic value of these resources when they see how much they are paid by biopirates. Thus, they are unaware of the size of the loss of their own future genetic resources when biopirates access these resources. This has made the people and the places they live in vulnerable to biopiracy and theft of genetic and biological resources (De Carvalho, 2000; Odek, 1994; Posey \& Dutfield, 1996). Sri Lanka finds this problem to be one of the key challenges of practicing positive ecotourism in the country. With the development of the tourism sector, over the last decades, smuggling and illicit trade in valuable flora and fauna have increased (Dellinger, 1995; Pleumarom, 1999; Subasinghe, 2013; Tella \& Hiraldo, 2014). When ecotourism is developed in the Kudawa-Sinharaja site, loss of forest genetic resources and wildlife smuggling are also increased with the influence of superimposed capitalism and its values [This idea was proved by SSI22, 27, 31, 29, 13, 34, 41].

A growing number of biopirates venture into Sinharaja for its genetic resources and they have understood that smuggling of biological material is easier and more successful if they cooperate with local indigenous people living at the forest peripheries. Thus, biopirates enter the targeted country posing as innocent tourists and they do not hesitate to pay large sums of local money to villagers who deal with them in genetic resources or wildlife smuggling. Regardless of all prevalent laws and regulations against bioprospecting, biopiracy, biological resource and wildlife smuggling, authorities have still failed to control these activities in the KudawaSinharaja site because of the support given to bio-pirates by the local community.

Local villagers possess an excellent knowledge about local genetic resources and are well aware of forest geography. Hence, they can quickly access the forest resources and collect them incognito. [SSI17-Environmentalist, 2015.09.14 (This statement was cross checked and was proved by SSI72, 76, 78, 27, \& FGI 05, 06)].

According to the records of the Kudawa-Sinharaja site, many international tourists have been charged with wildlife trafficking and biological and genetic resource theft (Forest Department, 2013a) but it has not discouraged the practice as is illustrated by these field observations.

On 18th September 2012, around eleven thirty in the morning a newly joined local site guide informed the forester about suspicious behaviour of an overseas tourist couple who had entered the site as eco-tourists. The forest officers on duty at the time hurried to the exit of the site to investigate the matter. They found the couple, a middle-aged man, and a woman, at the exit and requested to check their baggage before leaving the park premises. At first, they refused and the officers explained their right to check the baggage. Unwillingly and hesitantly, the couple opened their bags which were full of illegally collected orchid varieties of the park. Then the forest officers asked the couple to follow them to the forest office with the baggage for further investigation. The couple 
seemed to be in a dilemma about what to do next and one of the forest officers tried to collect the baggage from the woman. At that time, the woman was very angry and she suddenly bit the hand of the forest officer (Field note, 18.11.2012).

They had collected more than 300 orchid plants including 18 rare endemic species to Sri Lanka. A case was filed against them in the court and it was later revealed that the couple were Russian biologists with an excellent knowledge of Sri Lankan plant species and their local chauffeur guide had helped in the smuggling. They were proved guilty and fined SLR $1,200,000.00$ (about USD 9,213). The court ordered the convicted smugglers to leave the country immediately after paying the fine and their names have been blacklisted (Shantha, Padmabandu, \& Wijesooriya, 2012).

Since Gyrinops species are recognized as highly valuable and producers of agarwood many countries approve limited permits for agarwood-producing tree products to prevent the species being endangered by trade (Subasinghe, \& Hettiarachchi, 2013; 2015). Agarwood is valuable resinous heartwood of Thymalaeaceae family. Owing to the very high price on the international market for other commercially used species of agarwood, Gyrinops walla has been identified as a substitute. Recent information reveals that Gyrinops walla smuggling has occurred in Sri Lanka from last few years. The highest single amount discovered to be exported was 13,489 $\mathrm{kg}$ as recorded in May 2013. The data obtained from Sri Lanka police and customs depicts that over $17,500 \mathrm{~kg}$ of Gyrinops walla had been harvested in the last 12 months (Subasinghe, 2014).

Gyrinops walla is the only agarwood producing tree species of Sri Lanka (Subasinghe, \& Hettiarachchi, 2015) and it grows freely in Sinharaja. Even if this species has been recorded in some areas of South India, at present Gyrinops walla can only be seen in Sri Lanka (Subasinghe, Hettiarachchi \& Rathnamalala, 2012). As there are many freely growing Gyrinops walla trees in the Kudawa-Sinharaja site, paid local people enter the site looking for these trees to extract its resin. Within the last few years, a large number of Gyrinops walla trees have been destroyed from the harvest and smuggling of agarwood from the country (Dharmadasa, Siriwardana, Samarasinghe, \& Adhihetty, 2013; Subasinghe, 2014).

This research reveals that many locals are also involved in collecting agarwood, owing to its high demand and market value, which is even higher than the value of a gold sovereign (for the same weight) in Sri Lanka. During this field study, many local villagers and foreign tourists who were involved in gathering agar wood, which later deforms the Gyrinops walla tree, were arrested by the police with the support of forest officers. The issue of Gyrinops walla smuggling gradually increased and had become a serious biological issue by the middle of 2014. For example, three local villagers were arrested on 18.01 .2014 by the Sri Lankan police with their collected Gyrinops walla resins and at a rough government estimate, the market value of the collected resins was over SLR 100,000,000.00 (US\$ 767,725.00). However, these local villagers were ready to sell collected Gyrinops walla resin for 5,000,000.00 Rs (around US\$ 38,400) which was only one twentieth of the real market value (Ariyadasa, 2014).

Issues of biopiracy have also greatly increased within the last few years in the KudawaSinharaja site as well as in other rain forest areas of the country. For example, a new trend of 
Spotted Bow-finger Gecko (Cyrtodactylus triedra) smuggling was observed after 2012. This reptile is an endemic, rare and attractive species that can be seen in the rain forests of Sri Lanka (de Silva, 2006). During the years 2013 and 2014, many local villagers and some overseas tourists have been arrested by the police for spotted Bow-finger gecko smuggling [SSI21, 2012.09.24]
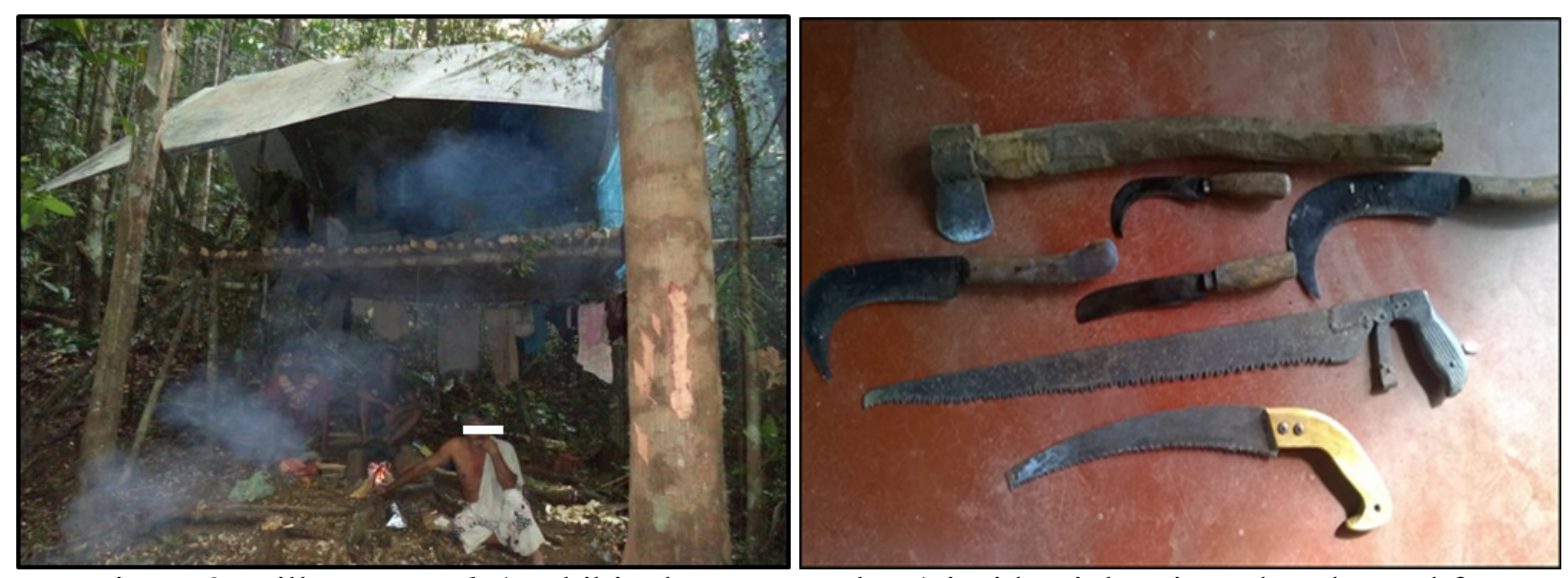

Figure 2: Villagers' vadi (prohibited temporary huts) inside Sinharaja and tools used for Gyrinops walla gathering

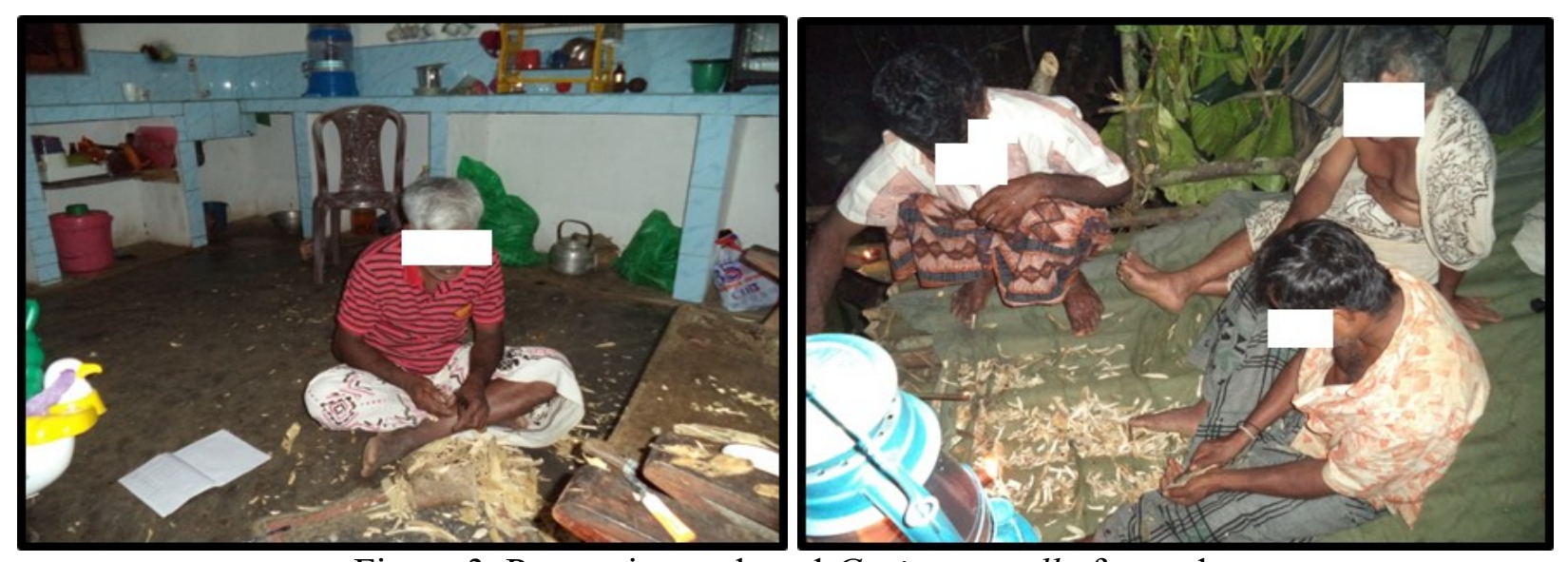

Figure 3. Processing gathered Gyrinops walla for trade

Photographed by Damith Kodithuwakku and published here with author's permission

\section{Discussion}

Development of ecotourism practices have created a new socio-economic structure in the Kudawa-Sinharaja site with superimposed capitalist values. This structure is different from western capitalism or the traditional Sri Lankan socio-economic system. As revealed in the research, superimposed capitalism has contributed to create an individualistic as well as consumeristic society and the traditions of the Kudawa GND communities nourished by traditional cultural and social values based on collectivism eroded rapidly. This sort of individualistic culture which is characterised by great competition among its members (even though they are related to each other either by descent or marriage) for economic status out of social envy can be identified as a major challenge in effective implementation of CBET (Foucat, 2002; Higham, 2007; Jamal et al., 2006; Nick, 2005; Ross \& Wall, 1999). It challenges 
achievement of realistic CBET targets in the Kudawa-Sinharaja site, so that benefit and resource distribution issues, environmental vulnerability and unethical ecotourism practices become prominent. Development of ecotourism in Kudawa-Sinharaja has opened the biodiversity rich Sinharaja rain forest to gene pirates and thus the virgin forest is prone to bioprospecting, biopiracy and wildlife smuggling. Even if some scholars have theoretically identified 'ecotourism' as a biosecurity management strategy (Fennell, 2007; Hall, 2007; Hill \& Gale, 2009), in practice the opposite has occurred in many southern peripheral countries of Africa, Latin America and Asia (Cater, 2004).

Regardless of all the strong policies and laws on biopiracy, Sri Lanka is still battling with gene pirates and the legal mechanism has not helped to resolve the problem totally (Forest Department, 2013a). In this situation, 'community empowerment' and 'collective leadership' theories can be used to design community based biodiversity protection programmes as a part of CBET projects implemented in the forest areas to minimize vulnerability. However, it should be noted here that changing socio economic values of the local communities of the Kudawa GND under superimposed capitalism could hinder the development of such community-based programmes. Therefore, educational and awareness raising programmes are necessary to help local people to recognize issues of biopiracy. If local villagers are capable of understanding the actual market values of genetic resources in their native lands, they would not be so easily cheated by genetic smugglers. On the other hand, the government together with the Forest Department can implement community-based programmes to plant marketable flora species like Gyrinops walla outside the reserve for international trade, which would benefit community members as well as the country's economy Without clear understanding of the individualistic social structure of Kudawa GND, any CBET project will be unable to achieve sustainable development goals. Some scholars have suggested to 'redesign ecotourism' practice, with special attention given to the concepts of 'cultural equity' and 'participatory practice' in order to minimise such an issue (Jamal et al., 2006). As Lappe explained, political and economic systems can be re-arranged and designed like a 'home garden, so that community structures can be redesigned under the notion of 'social empowerment' and 'collective responsibility' (Lappé, 2010, 2011, 2013). This view is useful to rearrange the CBET here.

\section{Conclusion}

Data analysis of this research discloses biopiracy issues as theoretical and practical socioeconomic challenges to CBET associated with sustainable bottom up development approach. Implementation of sustainable and bottom up development ideologies based on western alternative development approaches, can bring western capitalism into the particular context in the form of superimposed capitalism along with project activities. Most importantly, capitalist and superimposed capitalist values are ideologically against bottom up development values. Based on the research analysis, one of the main argument is that sustainable development discourse suffers from its own ideological and theoretical weaknesses as it lacks a mechanism to face the values of western capitalism merging into sustainable and bottom up development measures.

\section{References}

Ariyadasa, K.K., 2014. Ten crores of Gyrinops walla smuggling from Sinharaja. Lankadeepa (2014, January 18), p. 1.

Baker, S., 2012. Politics of sustainable development. Oxford, UK: Routledge. 
Baltar, F., \& Brunet, I., 2012. Social research 2.0: Virtual snowball sampling method using Facebook. Internet Research, 22(1), 57-74.

Becker, H.S., 1958. Problems of inference and proof in participant observation. American Sociological Review, 23(6), 652-660.

Boyatzis, R.E., 1998. Transforming qualitative information: Thematic analysis and code development. London, UK: Sage.

Brand, U., 2012. Green economy-the next oxymoron? No lessons learned from failures of implementing sustainable development. GAIA-Ecological Perspectives for Science and Society, 21(1), 28-32.

Brydon, D., 2004. Postcolonialism now: Autonomy, cosmopolitanism, and diaspora. University of Toronto Quarterly, 73(2), 691-706.

Bryman, A., 2012. Social research methods (4th ed.). Oxford, UK: Oxford University Press.

Cater, E., 2004. Ecotourism: Theory and practice. In A. A. Lew, C. M. Hall \& A. M. Williams (Eds.), $A$ companion to tourism (pp. 484-497). Oxford, UK: John Wiley \& Sons.

Chaperon, S., \& Bramwell, B. (2013). Dependency and agency in peripheral tourism development. Annals of Tourism Research, 40, 132-154.

Clark, R., 2008. Dependency, network integration, and development. Sociological Perspectives, 51(3), 629-648.

Cohen, N., \& Arieli, T., 2011. Field research in conflict environments: Methodological challenges and snowball sampling. Journal of Peace Research, 48(4), 423-435.

Dangal, S.P., \& De Silva, P.M.A., 2010. Community forest management in Sri Lanka: Lessons learnt and future direction. Retrieved from http://www.forestrynepal.org/images/02\%20Presented\%20Papers\%20and\%20Powerpoints/Theme\%201/Paper/07\%20Dangal\%20et\%20al Sri\%20Lanka.pdf, Accessed 26 June 2016.

De Carvalho, N.P., 2000. Requiring disclosure of the origin of genetic resources and prior informed consent in patent applications without infringing the TRIPS agreement: The problem and the solution. Washington University Journal of Law \& Policy, 2(1), 371-401.

De Munck, V.C., 1998. Lust, love, and arranged marriages in Sri Lanka. Westfort, India: Praeger Publication.

de Silva, A., 2006. Current status of the reptiles of Sri Lanka. Fauna of Sri Lanka, 11(1), 134-163.

Dellinger, B. (1995). Critical discourse analysis. Retrieved from http://httpserver.carleton.ca/ mflynnbu/discourse analysis/dellinger.htm, Accessed 08 July 2016.

Dewalt, K. M., 2011. Participant observation: A guide for fieldworkers (2nd ed.). Lanham, MD: Roman \& Littlefield.

Dey, I., 2003. Qualitative data analysis: A user-friendly guide for social scientists. London, UK: Routledge.

Dharmadasa, R., Siriwardana, A., Samarasinghe, K., \& Adhihetty, P., 2013. Standardization of Gyrops Walla (Thymalaeaceae) newly discovered, fragrant industrial potential, endemic plant from Sri Lanka. World Journal of Agricultural Research, 1(6), 101-103.

Dodds, K.J., 2014. Global geopolitics: A critical introduction. Oxford, UK: Routledge.

Fennell, D.A., 2007. Ecotourism. New York, NY: Routledge.

Fereday, J., \& Cochrane, E.M., 2008. Demonstrating rigor using thematic analysis: A hybrid approach of inductive and deductive coding and theme development. International Journal of Qualitative Methods, 5(1), 80-92.

Fernando, S.L.J., \& Shariff, N.M., 2013. Trends, environmental issues and challenges of ecotourism in Sri Lanka. Paper presented at the The 2013 IBEA, International Conference on Business, Economics, and Accounting, Bangkok, Thailand. Retrieved from http://www.caalinteduorg.com/ibea2013/ejournal/053---SLJ Fernando\&Noresah_Mohd SHariff---

Trends Environmental Issues and.pdf, Accessed 08 July 2016.

Forest Department, 2013a. Reports of Sinharaja Rain Forest. Ratnapura, Sri Lanka: Kudawa Forest Conservation Center 
Forest Department, 2013b. Sinharaja World Heritage Forest. Retrieved from http://www.forestdept.gov.lk/web/index.php?option=com_content\&view=article\&id=114\&Itemi $\mathrm{d}=116 \&$ lang=en\#Sinharaja, Accessed 08 July 2016.

Forest Department, 2014. Forest Department Sri Lanka. Retrieved from http://www.forestdept.gov.lk/web/index.php?lang=en, Accessed 06 July 2016.

Foucat, V., 2002. Community-based ecotourism management moving towards sustainability, in Ventanilla, Oaxaca, Mexico. Ocean and Coastal Management, 45(8), 511-529

Guillemin, M., \& Gillam, L., 2004. Ethics, reflexivity, and "ethically important moments" in research. Qualitative Inquiry, 10(2), 261-280.

Gunatilleke, I., Gunatilleke, C., \& Dilhan, M., 2005. Plant biogeography and conservation of the southwestern hill forests of Sri Lanka. The Raffles Bulletin of Zoology, 12(1), 9-22.

Hall, C.M., 2007. Biosecurity and ecotourism. In J. E. Higham (Ed.), Critical issues in ecotourism: Understanding a complex tourism phenomenon (pp. 102-116). London, UK Routledge.

Higham, J.E.S., 2007. Critical issues in ecotourism: Understanding a complex tourism phenomenon. London, UK: Routledge

Hill, J.L., \& Gale, T., (Eds.). 2009. Ecotourism and environmental sustainability: Principles and practice. Farnham, UK: Ashgate

Jalani, J.O., 2012. Local people's perception on the impacts and importance of ecotourism in Sabang, Palawan, Philippines. Procedia-Social and Behavioral Sciences, 57(1), 247-254.

Jamal, T., Borges, M., \& Stronza, A., 2006. The institutionalisation of ecotourism: Certification, cultural equity and praxis. Journal of Ecotourism, 5(3), 145-175.

Kahveci, G., Ok, K., \& Yýlmaz, E., 2011. Ecotourism and sustainable development of forests and forest villagers in Turkey. Retrieved from http://www.fao.org/DOCREP/ARTICLE/WFC/XII/0708A1.HTM, Accessed 09 July 2016.

Kamau, E. C., 2009. Sovereignty over genetic resources: Right to regulate access in a balance, the case of Kenya. Revista Internacional de Direitoe Cidadania, 3(1), 73-88.

Kumara, H. I. G. C. (2010). The policy intervention and the trends in forest utilization by local communities in Sinharaja (Unpublished Master of Philosophy). University of Peradeniya, Kandy, Sri Lanka.

Lappé, F.M., 2010. Diet for a small planet. New York, NY: Random House LLC.

Lappé, F.M., 2011. The city that ended hunger. In M. Gerwin (Ed.), Food and democracy (pp. 53). Kraków, Poland: Polish Green Network.

Lappé, F.M., 2013. Beyond the scarcity scare: reframing the discourse of hunger with an eco-mind. The Journal of Peasant Studies, 40(1), 219-238.

Longhurst, R., 2009. Interviews: In-depth, semi-structured. In N. J. Thrift \& R. Kitchin (Eds.), International encyclopedia of human geography (Vol. 10, pp. 580-584). Oxford, UK: Elsevier Science.

Lynam, T., Jong, W. D., Sheil, D., Kusumanto, T., \& Evans, K. (2007). A review of tools for incorporating community knowledge, preferences, and values into decision making in natural resources management. Ecology and Society, 12(1), 5. Retrieved from: http://www.ecologyandsociety.org/vol12/iss1/art5/, Accessed 11 July 2016.

May, T., 1997. Social research: Issues, methods, and process (2nd ed.). Philadelphia, PA: Open University Press.

McGilvray, D.B., 1982. Sexual power and fertility in Sri Lanka: Batticaloa Tamils and Moors. In C. MacCormack (Ed.), Ethnography of fertility and birth (pp. 25-73). London, UK: Academic Press.

Mgbeoji, I., 2005. Global biopiracy: Patents, plants, and indigenous knowledge. Vancouver, Canada: UBC Press.

Ngece, K., 2011. Community based ecotourism: What can the people of East Africa learn from success stories elsewhere? Nairobi, Kenya: East African Ecotourism Development and Conservation Consultants 
Odek, J., 1994. Bio-piracy: Creating proprietary rights in plant genetic resources. Journal of Intellectual Property Law, 2(1), 141-181.

Pawłowski, L., 2012. Do the liberal capitalism and globalization enable the implementation of sustainable development strategy? Problemy Ekorozwoju: Studia Filozoficzno-Sozologiczne, 7(2), 7-13.

Pleumarom, A., 1999. The hidden costs of the 'new'tourisms: A focus on biopiracy (Third World Network Briefing Paper for the Seventh Session of the UNCSD). New York, NY: UNCSD Publication.

Posey, D.A., \& Dutfield, G., 1996. Beyond intellectual property: Toward traditional resource rights for indigenous peoples and local communities. Ottawa, Canada: IDRC Publication.

Reimer, J.K., \& Walter, P., 2013. How do you know it when you see it? Community-based ecotourism in the Cardamom Mountains of southwestern Cambodia. Tourism Management, 34(1), 122-132.

Robert Wood Jonson Foundation. (2012). Qualitataive research guidelines project Retrieved from http://www.qualres.org/HomeRefl-3703.html, Accessed 10 July 2016.

Ross, S., \& Wall, G., 1999. Ecotourism: Towards congruence between theory and practice. Tourism Management, 20(1), 123-132

Samath, F., 2014. Sri Lanka: NGOs face funding gap and government scrutiny, http://www.ipsnews.net/2011/03/sri-lanka-ngos-face-funding-gap-and-government-scrutiny/, Accessed in 30 Aguest 2014.

Shantha, A.L., Padmabandu, W., \& Wijesooriya, A.U., 2012. Orchid plant collectors of Sinharaja have been punished. Lankadeepa, p. 4.

Sharma, P.K., 2012. Indigenous knowledge of plants and biopiracy in India. In R. Gupta (Ed.), Plant taxonomy: Past, present, and future (pp. 141). New Delhi, India: TERI Press.

Silva, K.T., Sivaparagasam, P.P., \& Thanges, P., 2009. Caste discrimination and social justice in Sri Lanka: An overview (Working Paper Series: Vol. 3, No 6). New Delhi, India: Indian Institute of Dalit Studies. Retrieved from http://idsn.org/fileadmin/user folder/pdf/New files/Publications from network/Caste discrimina tion_and_social_justice_in_Sri_Lanka_IIDS_working_paper_pdf, Accessed in 28 Aguest 2016.

Subasinghe, S., 2014. Agarwood production in Gyrinops walla (Walla patta): Myths and reality. In D. Jayawardana \& U. Subasinghe (Eds.), Proceedings of International Forestry and Environment Symposium. (Aliya Resort and Spa, Sigiriya, Sri Lanka): University of Sri Jayawardanapura.

Subasinghe, S.M.C.U.P., 2013. Plantation forestry in Sri Lanka: Challenges and constraints. Colombo, Sri Lanka: AGM of Institute of Biology.

Subasinghe, S.M.C.U.P., \& Hettiarachchi, D.S. 2013. Agarwood resin production and resin quality of Gyrinops walla Gaertn. Int. J. Agric. Sci, (3) 357-362.

Subasinghe, S.M.C.U.P., \& Hettiarachchi, D.S., 2015. Characterisation of agarwood type resin of Gyrinops walla Gaertn growing in selected populations in Sri Lanka. Industrial Crops and Products (69), 76-79.

Subasinghe, S.M.C.U.P., Hettiarachchi, D.S., \& Rathnamalala, E., 2012. Agarwood-type resin from Gyrinops walla Gaertn: a new discovery. Journal of Tropical Forestry and Environment, (2) 4449.

Tella, J.L., \& Hiraldo, F., 2014. Illegal and legal parrot trade shows a long-term, cross-cultural preference for the most attractive species increasing their risk of extinction. PloS One, 9(9), 1-10.

Thomas, L.J., 2012. Neoclassical development theory and the prebisch doctrine: A synthesis. American Economist, 38(1), 75-81.

Thompson, P.M., 2008. Conserving and restoring the benefits from Bangladesh wetlands. In J. Powell \& C. Short (Eds.), 12th International Association for the Study of Commons Conference (pp. 14-18): University of Gloucestershire, UK.

Vitarana, K.M., \& Rakaganno, R., 1997. Sri Lanka's forestry sector master plan. Retrieved from http://ces.iisc.ernet.in/hpg/envis/doc97html/ecolankaforest811.html, Accessed in 28 Aguest 2016.

Walker, S., Read, S., \& Priest, H., 2013. Use of reflexivity in a mixed-methods study. Nurse Researcher, 20(3), 38-43. 
Waylen, K.A., Gowan, P.J.K.M., \& Milner-Gulland, E.J., 2009. Ecotourism positively affects awareness and attitudes but not conservation behaviours: A case study at Grande Riviere, Trinidad. Oryx, 43(3), 343-351.

Ziai, A., 2011. Postcolonialism and development: Disparate tales reconsidered Development and Change, 42(5), 1297-1306. 